\title{
INTRODUCTION
}

\section{Modelling climate change impacts on crop production for food security}

\author{
M. Bindi ${ }^{1, *}$, T. Palosuo ${ }^{2}$, M. Trnka ${ }^{3,4}$, M. Semenov ${ }^{5}$ \\ ${ }^{1}$ University of Florence, 50144 Florence, Italy \\ ${ }^{2}$ Natural Resources Institute Finland (Luke), 00790 Helsinki, Finland \\ ${ }^{3}$ Institute of Agrosystems and Bioclimatology, Mendel University in Brno, Brno 613 00, Czech Republic \\ ${ }^{4}$ Global Change Research Centre AS CR,v.v.i., 60300 Brno, Czech Republic \\ ${ }^{5}$ Rothamsted Research, Harpenden, Herts AL5 2JQ, UK
}

\begin{abstract}
Process-based crop models that synthesise the latest scientific understanding of biophysical processes are currently the primary scientific tools available to assess potential impacts of climate change on crop production. Important obstacles are still present, however, and must be overcome for improving crop modelling application in integrated assessments of risk, of sustainability and of crop-production resilience in the face of climate change (e.g. uncertainty analysis, model integration, etc.). The research networks MACSUR and AGMIP organised the CropM International Symposium and Workshop in Oslo, on 10-12 February 2014, and present this CR Special, discussing the state-of-the-art-as well as future perspectives - of crop modelling applications in climate change risk assessment, including the challenges of integrated assessments for the agricultural sector.
\end{abstract}

KEY WORDS: Crop production · Climate change impact and adaptation assessments · Upscaling · Model ensembles

Resale or republication not permitted without written consent of the publishe

\section{Crop modelling applications for the assessment of climate change impacts}

Agricultural land pressure (e.g. land shortage and degradation), food security risks and the necessity to adapt to climate change increasingly require the modelling of future agro-ecosystems for the purpose of planning and decision making. Process-based crop simulation models are at the core of any climate impact assessment for the agricultural sector. However, neither the modelling approaches nor the crop simulation tools are at present fully up to the task (Knutti 2010, Rosenzweig \& Wilbanks 2010, Rötter et al. 2011). For example, most crop simulation models do not account for crop-specific abiotic and biotic stresses (e.g. climate extreme events, pests, and diseases). Moreover, their application for large-area assessments has been done without properly considering time and spatial up-scaling issues. These and other deficiencies lead to uncertainties, which are often not quantified.

The crop modelling (CropM) component of the FACCE JPI knowledge hub MACSUR (www.macsur. eu) and other agricultural research projects and networks (e.g. AgMIP and CCAFS) are designed to improve the prediction of climate impacts on agriculture. The last international symposium on crop model capabilities, along with the gaps and challenges associated with this, was held more than 10 years ago. Responding for this need for more up-todate information and analysis, the CropM International Symposium and Workshop was held in Oslo on 10-12 February 2014 to discuss the state-of-the-artalong with future perspectives - of crop modelling and approaches for climate change risk assessment, including the challenges of integrated assessments for the agricultural sector. 


\section{Contributions to this CR Special}

The contributions to this CR Special focus on:

(1) Improvement of tools and applications in climate change assessments (Ferrise et al. 2015, Tao et al. 2015).

(2) Assessment of uncertainty in the modelling of impacts in agriculture, e.g. in upscaling, and in climate and crop model ensembles (Baranowski et al. 2015, Hoffmann et al. 2015, Persson et al. 2015, Pirttioja et al. 2015, Salack et al. 2015, Semenov \& Stratonovitch 2015, Zhao et al. 2015).

(3) Assessment of impacts and adaptation strategies (Gabaldón-Leal et al. 2015, Hlavinka et al. 2015, Karunaratne et al. 2015, Mitter et al. 2015, Palosuo et al. 2015).

\section{Principal messages}

Most early crop simulation models were not primarily developed for the study of climate change impacts, but crop-modelling studies for climate impact research have more recently been substantially elaborated on. Explicit attention has been given to ways of improving descriptions of different adaptations (e.g. use of improved crop cultivars, soil and crop management) and abiotic and biotic stresses. In addition, methods assessing and reducing uncertainties related to model applications, such as multi-model ensemble simulation and upscaling studies, have been further developed (Ewert et al. 2015).

This CR Special highlights potential uses of crop models, for example in combination with seasonal climate forecasts and long-term climate scenarios for climate change impact assessments. Climate and crop model ensembles and upscaling applications can improve accuracy, as well as the analysis of uncertainties, in crop responses. Finally, in studies on adaptation strategies, the use of crop models within integrated modelling frameworks (e.g. statistical climate change models, crop rotation models, biophysical process models, and economic bottom-up land use optimization models) was demonstrated and further developed.

The contributions this CR Special further highlight the importance of accuracy in process descriptions and model calibrations for simulated results. For adaptation studies in particular, the responses of models to changes in soil and crop management were shown to be essential. Finally, the availability of highquality data for model calibration and testing was seen as a major limiting factor to model improvement.
Acknowledgements. We are grateful to all colleagues who were instrumental in bringing about this CR Special by submitting abstracts and papers. We are also in debt to all reviewers who provided their expert opinion to improve the quality of the submitted manuscripts.

\section{LITERATURE CITED}

Baranowski P, Krzyszczak J, Slawinski C, Hoffmann H and others (2015) Multifractal analysis of meteorological time series to assess climate impacts. Clim Res 65:39-52

Ewert F, Rötter RP, Bindi M, Webber H and others (2015) Crop modelling for integrated assessment of risk to food production from climate change. Environ Model Softw. doi:10.1016/j.envsoft.2014.12.003

Ferrise R, Toscano P, Pasqui M, Moriondo M, Primicerio J, Semenov MA, Bindi M (2015) Monthly-to-seasonal predictions of durum wheat yield over the Mediterranean Basin. Clim Res 65:7-21

Gabaldón-Leal C, Lorite IJ, Mínguez MI, Lizaso JI, Dosio A, Sanchez E, Ruiz-Ramos M (2015) Strategies for adapting maize to climate change and extreme temperatures in Andalusia, Spain. Clim Res 65:159-173

Hlavinka P, Kersebaum KC, Dubrovský M, Fischer M and others (2015) Water balance, drought stress and yields for rainfed field crop rotations under present and future conditions in the Czech Republic. Clim Res 65:175-191

Hoffmann H, Zhao G, van Bussel LGJ, Enders A, and others (2015) Variability of effects of spatial climate data aggregation on regional yield simulation by crop models. Clim Res 65:53-69

Karunaratne AS, Walker S, Ruane AC (2015) Modelling bambara groundnut yield in Southern Africa: towards a climate resilient future. Clim Res 65:193-203

Knutti R (2010) The end of model democracy? An editorial comment. Clim Change 102:395-404

> Mitter M, Schmid E, Sinabell F (2015) Integrated modeling of protein crop production responses to climate change and agricultural policy scenarios in Austria. Clim Res 65: 205-220

Palosuo T, Rötter RP, Salo T, Peltonen-Sainio P, Tao F, Lehtonen H (2015) Effects of climate and historical adaptation measures on barley yield trends in Finland. Clim Res 65: 221-236

> Persson T, Kværnø S, Höglind M (2015) Impact of soil type extrapolation on timothy grass yield under baseline and future climate conditions in southeastern Norway. Clim Res 65:71-86

Pirttioja N, Carter TR, Fronzek S, Bindi M and others (2015) Temperature and precipitation effects on wheat yield across a European transect: a crop model ensemble analysis using impact response surfaces. Clim Res 65: 87-105

> Rosenzweig C, Wilbanks TJ (2010) The state of climate change vulnerability, impacts, and adaptation research: strengthening knowledge base and community. Clim Change 100:103-106

Rötter RP, Carter TR, Olesen JE, Porter JR (2011) Cropclimate models need an overhaul. Nat Clim Change 1: 175-177

Salack S, Sarr B, Sangare SK, Ly M, Sanda IS, Kunstmann H (2015) Crop-climate ensemble scenarios to improve risks assessment and resilience in the semi-arid regions of West Africa. Clim Res 65:107-121 
Semenov MA, Stratonovitch P (2015) Adapting wheat ideotypes for climate change: accounting for uncertainties in CMIP5 climate projections. Clim Res 65:123-139

Tao F, Rötter RP, Palosuo T, Höhn J, Peltonen-Sainio P, Rajala A, Salo T (2015) Assessing climate effects on wheat yield and water use in Finland using a super-

Submitted: June 11, 2014; Accepted: November 3, 2014 ensemble-based probabilistic approach. Clim Res 65: 23-37

Zhao G, Hoffmann H, van Bussel LGJ, Enders A and others (2015) Effect of weather data aggregation on regional crop simulation for different crops, production conditions and response variables. Clim Res 65:141-157

Proofs received from author(s): September 25, 2015 